of these creatures is prefigured by the tracheation. After publishing his well-known book "The Biology of Dragonflies" (1917), Tillyard completed a study of venation and its bearings on the phylogeny of the Holometabola. The outcome were his papers on the "Panorpoid Complex" wherein, by a closely reasoned analysis, he claimed that under this title were to be grouped all the higher orders other than the Coleoptera and Hymenoptera.

Tillyard's many contributions on fossil insects placed him as the foremost authority on the subject in his day. The rich beds of Upper Triassic and Lower Permian age in Australia, and of Lower Permian date of Kansas, provided him with a wealth of material. In a relatively short time, Tillyard did much towards changing our knowledge of Permian and Triassic insects from being the most fragmentary into becoming among the most complete of any geological period. He also made many remarkable accessions to our knowledge of the affinities of various orders in bringing to light generalized or annectant types. With so extensive an output of work to his credit, it is scarcely surprising that here and there his conclusions led him astray.

After resigning his last appointment, Tillyard regained much of his health, and one of his last efforts was a conjoint memoir with the late Sir W. T. E. David on Proterozoic fossils of the Adelaide Series (1936). Only three weeks ago a letter by him in NATURE (January 9) made known a Mecopteroid insect bearing upon the ancestry of Diptera.

As an applied entomologist, Tillyard's notable work was the successful introduction of the Chalcid, Aphelinus mali, into New Zealand. As an agent controlling the woolly aphis of the apple, it greatly benefited growers by minimizing the necessity for insecticides. Tillyard was a whole-hearted believer in biological control, and initiated schemes for the repression of noxious plants, by introduced phytophagous insects, for both New Zealand and Australia. The results, however, have not, so far, borne out his earlier expectations.

Tillyard's predominant interest was in insect phylogeny and, in this connexion, he published papers on almost all the lower orders and especially on the more primitive forms. Altogether, he must have published about two hundred papers. The great part of this work is of high quality and will aid and stimulate those who come after him. He also found time to write a large text-book on the "Insects of Australia and New Zealand" (1926), profusely illustrated from drawings made by his wife.

For a number of years past Tillyard was keenly interested in psychical phenomena. At one time, these matters absorbed his attention to an extent which perplexed some who knew him. He believed in the necessity for proper scientific analysis of such manifestations and took every opportunity of gaining first-hand experience.

At the time of his death, Tillyard was an honorary fellow of Queens' College, Cambridge : he graduated Sc.D. (Cantab.) in 1920 and became F.R.S. in 1925. $\mathrm{He}$ is survived by his wife and four daughters.

A. D. IMms.

\section{Sir David Semple}

WE regret to record the death, which occurred on January 7 at the age of eighty years, of Sir David Semple. Sir David graduated with honours at Queen's University, Belfast, and also took a diploma in public health before entering the Army Medical Corps, as it then was, as early as 1883 . After service in India and elsewhere, he became associated with Almroth Wright as assistant professor of pathology at the Army Medical School at Netley from 1904 until 1909, and the good work he then did in bacteriological research opened up a varied and valuable career. Much of his earlier work was in connexion with anti-typhoid inoculation and other immunological researches, and this led to his appointment as a member of the committee for investigation of enteric fever in India from 1905 until 1909; this committee did important work which led to enteric being dethroned from its unenviable position of constituting by far the most important cause of sickness and mortality in the British Army in India.

In 1905 the first Pasteur Institute of India was founded at Kasauli in the Himalayas, not far from Simla, under a committee which had been largely instrumental in raising funds for its establishment, and David Semple's reputation already stood so high that he was selected as the first director during the early critical years, 1900-5. Here he did what was probably his most important work in introducing the use of carbolized hydrophobia-infected rabbits nervous system in graduated doses; for this has enabled the vaccine to be preserved and sent for use to hospitals and dispensaries all over India, with the great advantages of enabling the treatment to be carried out without the delay and expense of sending the patients many hundreds of miles to a central Pasteur Institute.

In 1905 Semple was called upon to occupy the more important post of director of the newly established Central Research Institute of India, also at Kasauli, which was now organized as the headquarters of the newly established Bacteriological Department of the Government of India for general medical research purposes. He had now completed more than twenty years service in the Royal Army Medical Corps, as it had now become, so he retired from that service with a pension, and served in his new post until 1913. During a portion of that time he was a member of the Central Malarial Committee and of the Scientific Advisory Committee for Medical Research under the Government of India. His work was now mainly of an administrative nature, and he did much to help and encourage younger research workers attached to the Research Institute. On retiring from service in India under the age rules in 1913, he was fortunate enough to find fresh administrative employment in Egypt as Director-General of the Public Health Department from 1913 until 1918, when he eventually returned to England to a well-earned rest.

Semple was of a retiring disposition, but a sound patient worker, and it was only those who had the privilege of his friendship who fully appreciated his worth. 